\title{
Mantle Xenoliths from Canastra-01 kimberlite, Brazil
}

\author{
Giulianna V. Costa ${ }^{1}$; José Carlos Gaspar ${ }^{1}$; Renato Moraes ${ }^{2}$; Aline T. M. Coelho-Silva ${ }^{1}$; \\ Saulo Carreiro ${ }^{1}$ \\ ${ }^{1}$ Dept. of Geoscience, Brasília University, Brasília, Brazil \\ ${ }^{2}$ Dept. of mineralogy and geothectonic, São Paulo University, São Paulo, Brazil
}

Canastra-01 kimberlite is located in the southern portion of São Francisco Craton, Brazil and is known as diamondiferous. This intrusion comprises two adjacent pipes with 0.8 and 1.0 hectare, respectively, located in NW and SE of Córrego da Cachoeira, Minas Gerais State, Brazil. Mantle xenoliths were sampled and comprise: garnet cliopyroxenite, eclogite, amphibole websterites (with or without garnet and spinel), garnet lherzolite, garnet harzburgite, spinel harzburgite and dunite. The aim of this work is to characterize the chemistry of their minerals by electron microprobe analysis and the $P-T$ equilibrium conditions. Several of geothermobarometers were utilized based on present mineral assemblage as indicated by Brey et al. (2008).

Garnet $\quad\left(\mathrm{Pyr}_{73.0} \quad \mathrm{Alm}_{13.9} \quad \mathrm{Gro}_{3.7}\right)$ lherzolite is porfiroclastic with an olivine $\left(\mathrm{Fo}_{89.2}\right.$ to 90.9$)$ mosaic groundmass, augite and bronzite. Garnet $\left(\mathrm{Pyr}_{73.0}\right.$ $\mathrm{Alm}_{13.3} \mathrm{Gro}_{4.9}$ ) harzburgite is porfiroclastic with an olivine ( $\mathrm{Fo}_{90.0}$ to 91.2 ) mosaic groundmass, bronzite and enstatite. Spinel harzburgite have granoblastic texture, made of augite, enstatite, olivine $\left(\mathrm{Fo}_{91.1}\right.$ to 92.2$)$ and spinel $\left(\mathrm{Mg}_{0.69} \mathrm{Fe}_{0.31} \mathrm{Cr}_{0.70} \mathrm{Al}_{1.3} \mathrm{O}_{32}\right)$. $\mathrm{Ni}$ and $\mathrm{Fo}$ correlation shows that the $\mathrm{Ni}$ content is independent of Fo content in the garnet lherzolite and spinel harzburgite; in garnet harzburgite there is a negative correlation between $\mathrm{Ni}$ and Fo. In both cases, no correlation and negative correlation indicate an origin by partial melting for these xenoliths. Dunite contains only olivine $\left(\mathrm{FO}_{89.3}\right.$ to 91.1 ), and is considered as a residue after peridotite partial melting, as indicated by the negative $\mathrm{Ni}$ and Fo correlation.

Websterite presents a coarse granoblastic texture and the main minerals are: diopside, bronzite, pargasite to $\mathrm{Mg}-\mathrm{Al}$-sadanagaite in the garnet and spinel types and $\mathrm{Mg}$-hornblende in the amphibole websterite. Spinel presents composition $\mathrm{Mg}_{0.55} \mathrm{Fe}_{0.45} \mathrm{Al}_{2} \mathrm{O}_{32}$ and garnet $\mathrm{Pyr}_{45.7} \mathrm{Alm}_{37.5} \mathrm{Gro}_{1.0}$.

Mineral compositions of garnet clinopyroxenite and eclogite are pyrope-alamandine garnet and augite in garnet clinopyroxenite and onfacite in eclogite.
$P-T$ average results of the xenoliths calculated with protocol proposed by Brey et al. (2008) are showed in Table 1. Figure 1 is a plot of $P$ and $T$ average calculated for the Canastra-o1 xenoliths. The $P T$ diagram shows that xenoliths $P-T$ results spread in an approximate geotherm from 40 to $60 \mathrm{~mW} / \mathrm{m}^{2}$. Garnet lherzolite samples are within the diamond stability field, except for one xenolith. Garnet harzburgite are within the graphite stability field.

\begin{tabular}{lcc}
\hline & $\boldsymbol{T}\left({ }^{\circ} \mathbf{C}\right)$ & $\boldsymbol{P}$ (kbar) \\
\hline garnet lherzolite & 1160 to 1412 & 49 to 55 \\
garnet harzburgite & 1120 to 1423 & 42 to 46 \\
spinel harzburgite & 710 to 751 & - \\
$\begin{array}{l}\text { amphibole-garnet } \\
\text { websterite }\end{array}$ & 600 to 989 & - \\
$\begin{array}{l}\text { spinel amphibole } \\
\text { websterite }\end{array}$ & 812 & - \\
amphibole websterite & 762 & - \\
garnet clinopyroxenite & 1255 & - \\
eclogite & 980 & - \\
\hline
\end{tabular}

Table 1. $P T$ average range of the Canastra-01 xenoliths.

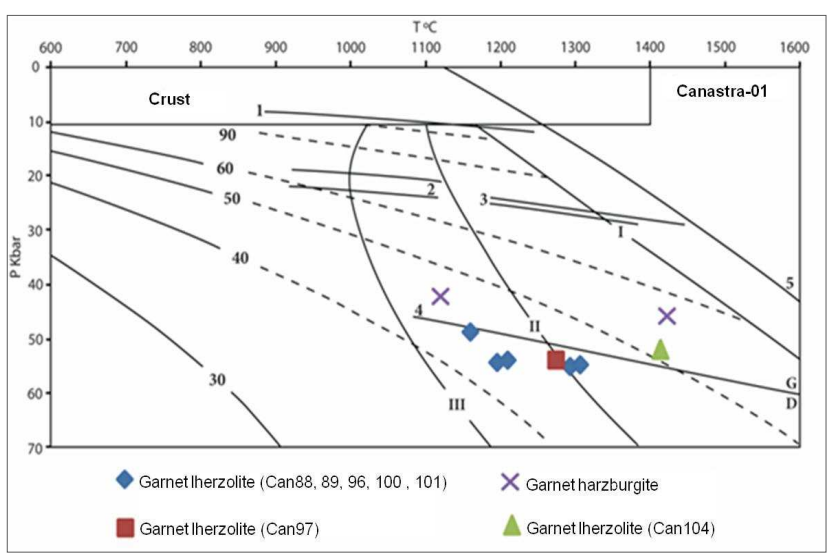

Figure 1. Average $P T$ data plot for Canastra- 01 xenoliths. The curves showing the values of 30 to 90 correspond to the respective geotherms values in $\mathrm{mW} / \mathrm{m}^{2}$ (Pollack et al., 1993). Lines I, II and III are solidus for the mantle: I. Volatile free; II. Mixed volatile; III. Hydrous (Pollack et al., 1993). The area above $10 \mathrm{kbar}$ corresponds to the continental crust (Pollack et al., 1993). Lines 1, 2 and 3 correspond to: 1. 
Plagioclase and spinel facies limit; 2 and 3 garnet in (low $P$ ) and spinel out (high $P$ ) limit; 5. Solidus for the mantle, according to Hirschmann (2000). G/D line indicate the graphite-diamond boundary of Kennedy and Kennedy (1976).

$P-T$ data for garnet grains from Canastra-01 kimberlite were determined by Ni-thermometry (Winter, 1997) and are presented to $P-T$ data for xenoliths. Two temperature intervals were defined for $\mathrm{NW}$ pipe (barren pipe): low $T\left(700^{\circ} \mathrm{C}\right.$ to $\left.900^{\circ} \mathrm{C}\right)$ and high $T$ (> $\left.1000^{\circ} \mathrm{C}\right)$. Temperature for the $\mathrm{SE}$ pipe (diamondiferous) range from $600^{\circ} \mathrm{C}$ to $1400^{\circ} \mathrm{C}$. For both pipes the minimum geotherm is $40 \mathrm{~mW} / \mathrm{m}^{2}$.

The mineral chemistry of Três Ranchos IV xenoliths (Carvalho, 1997) is used to calculate their $P-T$ equilibrium conditions. Três Ranchos IV is a kimberlitic intrusion intruded into the Brasília Mobile Belt and had sampled mantle xenoliths that comprise: garnet lherzolite, spinel-flogophite lherzolite, olivine websterite, garnet wehrlite and spinel wehrlite. The same method used to calculate $P-T$ conditions for mantle xenoliths from Canastra-01 is applied here for Três Ranchos IV xenolits and average $P-T$ data is presented in Table 2 and Figure 2.

Table 2. $P-T$ average of the Três Ranchos IV xenoliths.

\begin{tabular}{lcc}
\hline & $\boldsymbol{T}\left({ }^{\circ} \mathbf{C}\right)$ & $\boldsymbol{P}(\mathbf{k b a r})$ \\
\hline garnet lherzolite & 982 to 1160 & 38 to 47 \\
garnet wehrlite & 1463 & 40 \\
olivine websterite & 817 & - \\
$\begin{array}{l}\text { spinel-phlogopite } \\
\text { lherzolite }\end{array}$ & 785 & - \\
\hline
\end{tabular}

Figure 2 shows that one garnet lherzolite plots within the diamond stability field, if it is projected to lower $T$. A second garnet lherzolite and the garnet wehrlite both plot within the graphite stability field.

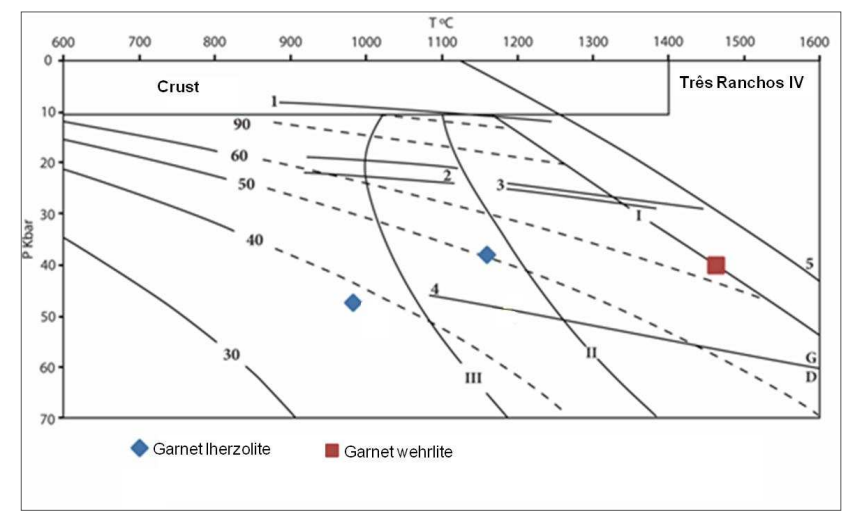

Figure 2. Average $P$ - $T$ for Três Ranchos IV xenoliths. Lines and fields as in Figure 1.

\section{Tectonic environment and diamond mineralization}

Table 3 shows a comparision among the $P-T$ and the corresponding geotherms to the Canastra-01 xenolits and garnets, and Três Ranchos IV xenoliths.

Table 3. Ranges of temperature, pressure, and geotherms for Canastra-01 xenoliths and garnet grains, and Três Ranchos IV xenoliths.

\begin{tabular}{l|c|c|c}
\hline & $\boldsymbol{T}\left({ }^{\circ} \mathbf{C}\right)$ & $\boldsymbol{P}(\mathbf{k b a r})$ & $\begin{array}{c}\text { Geotherm } \\
\left(\mathbf{m W} / \mathbf{m}^{2}\right)\end{array}$ \\
\hline $\begin{array}{l}\text { Canastra-01 } \\
\text { xenoliths }\end{array}$ & 1050 to 1450 & 35 to 65 & 40 to 60 \\
\hline $\begin{array}{l}\text { Canastra-01 } \\
\text { garnets }\end{array}$ & 600 to 1400 & 17 to 52 & 32 to 70 \\
\hline $\begin{array}{l}\text { Três Ranchos } \\
\text { IV xenoliths }\end{array}$ & 785 to 1463 & 38 to 47 & 38 to 63 \\
\hline
\end{tabular}

$P-T$ arrays of xenoliths from Canastra-01 spread between 40 to $60 \mathrm{~mW} / \mathrm{m}^{2}$ geotherms. Três Ranchos IV xenoliths spread in geotherm interval 38 to $63 \mathrm{~mW} / \mathrm{m}^{2}$. We propose that a geotherm of around $38-40 \mathrm{~mW} / \mathrm{m}^{2}$ was present before the Brasiliano Orogeny. During the orogeny the geotherm increased to about 60-63 $\mathrm{mW} / \mathrm{m}^{2}$. The similar ranges of $P-T$ conditions sampled by Canastra- 01 and Três Ranchos IV kimberlites suggest that cratonic mantle portions were not completely re-equilibrated by the orogeny. Diamonds were preserved in the non or partially re-equilibrated cratonic relicts underlain the southwestern border of São Francisco Craton and the Brasília Mobile Belt.

\section{Reference}

Brey, G. P., Bulatov, V. K., Girnis, A. V. 2008. Geobarometry for peridotites: experiments in simple and natural systems for 6 to $10 \mathrm{GPa}$. Journal of Petrology, 49 (1): 3-24.

Carvalho, J. B. 1997. Petrologia de xenólitos mantélicos da Província do Alto Paranaíba, Minas Gerais e Goiás. Tese de Doutorado, Instituto de Geociências, Universidade de Brasília, 395 p.

Hirschmann, M. M. 2000. Mantle solidus: experimental constraints and the effects of peridotite composition. Geochemistry, Geophysics Geosystems, 1 (2000GC000070).

Kennedy, C. S., Kennedy, G. C. 1976. The equilibrium boundary between graphite and diamond. Journal of Geophysical Research, 81 (14): 2467-2470. 
Pollack, H.N., Hurter, S. J., Johnson, J. R. 1993. Heat flow from the Earth's interior: analysis of the global data set. Reviews of Geophysics, 31 (3): 267-280.

Winter, F. 1997. A detailed evaluation of the major and trace-element mineral chemistry of the Canastra-01 occurrence, Minas Gerais south, Brazil. SOPEMI/ AARL report ARL97/0109: 12 pp. 